\title{
The Naïve B Cells are the Lymphocytes with the Highest Anionic Phospholipid Binding Ratios
}

\author{
Mohamed Moumaris $^{1,2}$, Bakoliarisoa Rajoely ${ }^{1,2}$ and Nisen Abuaf ${ }^{*}, 1,2$ \\ ${ }^{1}$ Hôpital Rothschild and ${ }^{2}$ Hôpital Tenon, AP-HP and Université Pierre et Marie-Curie, Paris
}

\begin{abstract}
Phospholipids (PLs) are the target for the clearance of apoptotic cells, and for the innate defense against malignant cancers or microbial infections. Several types of receptors for PLs were described on T lymphocytes, but not yet on B lymphocytes. To detect PLs binding lymphocytes two assays were used: a- FITC labelled liposomes, b- Petri dish coated with different PLs. The phenotype of lymphocytes was determined by FACS, using anti-CD mAb and anti-Ig polyclonal antibodies. Human lymphocytes bind PLs, the binding ratio decreases in the order phosphatidylserine (PS), cardiolipin (CL), phosphatidylethanolamine, and phosphatidylcholine. In healthy blood donors ( $\mathrm{n}=17), 29 \%$ of B lymphocytes, $17 \%$ of NK cells, $9 \%$ of TCD $4^{+}$, and $4 \%$ of TCD $8{ }^{+}$bind PS. Among B cells, the binding ratio varies with the subset, $49 \%$ for naïve cells $\left(\operatorname{sIgM}^{+} \operatorname{sIgD}^{+}\right), 42 \%$ for $\operatorname{sIgA} A^{+}$, and $15 \%$ for $\operatorname{sIgG}^{+} \mathrm{B}$ cells. PL binding was not affected by the CD5 phenotype of B lymphocytes, nor by the HIV status of the donors $(n=16)$ or the presence in the sera of $\operatorname{IgG}$ anti$\mathrm{CL}$ antibodies. Pretreatment of lymphocytes with proteases inhibited the binding of PL, suggesting that binding is due to surface proteins. For each type of lymphocytes the various kinds of surface proteins which bind lipids, pattern recognition receptors, surface immunoglobulins, the lipid antigen presenting molecules CD1, and the CD1-restricted lipid antigen reactive TCR of NKT cells, are discussed.
\end{abstract}

Keywords: AIDS, apoptosis, autoantibodies, innate immunity, naïve B lymphocytes, phospholipids, T lymphocytes.

\section{INTRODUCTION}

In healthy cells, phosphatidylserine (PS) is located in the inner layer of the plasma membrane, and cardiolipin (CL) is exclusively situated in the inner mitochondrial membrane. Phosphatidylethanolamine (PE) and phosphatidylcholine (PC) are sharing between the inner leaflet and the outer leaflet of the plasma membrane. Disruption of membrane asymmetry is observed in platelet activation, aging cells, and during cell death by necrosis or apoptosis [1-5]. Membrane lipid scrambling is strongly correlated with evaginations of cell surface and shedding of small membrane vesicles [1].

Externalization of PS is a hallmark of the changes in the cell surface during apoptosis. PS spot to the inner leaflet of the plasma membrane; when the cell undergoes apoptosis, it is liable on the outer leaflet. PS on apoptotic cells provides a signal that initiates cell engulfment [6, 7]. Translocated PS produces a ligand by which apoptotic or dead cells are recognized by phagocyte cells and lymphocytes; candidate proteins are suggested as a PS specific receptor expressed on the surface of phagocyte cells and lymphocytes [8-10]. Moreover, anti-phospholipid antibodies (aPL) bind apoptotic cells and might contribute to their elimination by mononuclear phagocytes; aPL were described in the antiphospholipid syndrome [1].

Lymphocyte might be able to recognize the loss of plasma membrane asymmetry, and to bind specifically some PLs like PS and PE, then could contribute to the clearance of

\footnotetext{
*Address correspondence to this author at the Service d'Hématologie et d'Immunologie Biologique, Hôpital Tenon, 4 rue de la Chine, 75970 PARIS Cedex 20, France; Tel: 0033156017343; Fax: 0033156017780;

E-mail: nissen.abuaf@tnn.aphp.fr
}

apoptotic cells or induce inflammatory response against necrotic or cancer cells. There is growing evidence that $\mathrm{T}$ cells having TIM receptors for PLs or CD1d-restricted, lipid antigen-reactive Natural killer $\mathrm{T}$ cells (NKT) have a powerful immunoregulatory potential [10-13].

The aim of this study was to identify the lymphocytes subsets with the highest binding ratio for the PLs PS, PC, PE and $\mathrm{CL}$, and to compare the binding ratios of patients with altered lymphocytes subsets, AIDS to healthy donors. For this purpose we developed two techniques for isolating and identifying lymphocytes binding phospholipids.

\section{MATERIALS AND METHODS}

\subsection{Phospholipid Coated Petri Dish [14]}

Cardiolipin (CL) from bovine heart, L-a-phosphatidyl-Lserine dipalmitoyl (PS), L-a-phosphatidylcholine (PC) from frozen egg yolk type XIII-E, or L-a-phosphatidylethanolamine dipalmitoyl (PE) (Sigma, Saint-Quentin Fallavier, France) were dissolved at $0.48 \mathrm{mg}$ in $9 \mathrm{ml}$ of ethanol (Carlo Erba, Val de reuil, France). $1.5 \mathrm{ml}$ of the solution was used to coat a plastic Petri dish $(35 \times 10$, Corning, NY, NY). An overnight incubation at $4^{\circ} \mathrm{C}$ was used to evaporate the solvent. The binding of lymphocytes to control Petri dishes increased when proteins were used to saturate the plastic. Therefore the Petri dishes were not saturated.

\subsection{Phosphatidylserine Liposomes (PSL) Preparation $[15,16]$}

Solution of PS $(300 \mu \mathrm{g} / \mathrm{ml})$ in chloroform (Carlo Erba) was evaporated in a glass tube. Then $50 \mu 1$ of $10 \mathrm{mg} / \mathrm{ml}$ fluorescein conjugated albumin (Sigma) and $950 \mu 1$ of PBS (bio-Mérieux, Marcy l'Etoile, France) were added on the 
phospholipid film; and sonicated for 15 minutes at $35 \mathrm{kHz}$ on a Gen-probe sonicator (Elma-Hans Schmidbauer, Singen, Germany). FITC-albumin labelled liposomes were separated from free FITC-albumin by Sepharose 6B (Pharmacia, SaintQuentin en Yvelines, France) gel filtration chromatography. Liposomes with other PLs were prepared in the same technical conditions as PSL.

\subsection{Antibodies}

R-Phycoerythrin (RD1) conjugated anti-CD4 and antiCD56, and tandem dye R-Phycoerythrin-Texas red (ECD) conjugated anti-CD3 and anti-CD19 $\mathrm{mAb}$ were purchased from Coulter-Immunotech, Margency, France. FITC conjugated affinity isolated goat $F\left(a b^{\prime}\right) 2$ anti-human $\operatorname{Ig}(\mathrm{G}, \mathrm{A}$, $\mathrm{M}$ or D) antibodies were purchased from Tago, Burlingame, CA.

\subsection{Isolation of Lymphocytes and Analysis by Flow Cytometry [15]}

\subsubsection{Cells Isolation}

Cell donors were healthy subjects $(n=17)$ and AIDS patients $(\mathrm{n}=16)$. HIV infection and AIDS were diagnosed according to criteria of the CDC [17]. The study protocol was in accordance with the local ethical committee guidelines.

Peripheral blood mononuclear cells were isolated from EDTA anticoagulated blood (Vacutainer $7 \mathrm{ml}$ plastic tubes, Beckton Dickinson, Le Pont de Claix, France) by centrifugation at $500 \mathrm{~g}$ for 20 minutes at $20^{\circ} \mathrm{C}$ on a layer of Ficoll $(\mathrm{d}=1.077)$ (Eurobio, Les Ulis, France), then washed with RPMI medium (Gibco, Cergy Pontoise, France) and adjusted to $5 \times 10^{5}$ cells $/ \mathrm{ml}$.

\subsubsection{Petri Dish and Liposomes Assays}

In the assays with Petri dish coated with PL, $1 \mathrm{ml}$ of cell suspension was layered on and incubated at room temperature for $30 \mathrm{~min}$. After washing for three times, the adhering cells were harvested with a rubber policeman and washed in RPMI. Then the cells were labelled with $\mathrm{mAb}$ to $\mathrm{CD}$ antigens or affinity isolated goat $\mathrm{F}\left(\mathrm{ab} \mathrm{b}^{\prime}\right) 2$ anti-human $\operatorname{Ig}(\mathrm{G}, \mathrm{A}, \mathrm{M}$ or D) antibodies and analyzed on an Epics XL 4 colour flow cytometer (Beckman Coulter, Marseille, France).

In the assays with liposomes, $1 \mathrm{ml}$ of cell suspension is mixed by very gentle rotation on a rotator (Carteau et Ots, Bagnolet, France) with $0.1 \mathrm{ml}$ freshly prepared PSL for 15 min at room temperature; then washed with RPMI, stained with anti-CD mAb and analysed by flow cytometry.

\subsection{Anti-Phospholipid Antibodies (aPL)}

ELISA was used to detect aPL in the technical conditions that we previously described [13].

\subsection{Enzymatic Treatment of Lymphocytes}

$0.3 \mathrm{ml}$ of cell suspension are incubated at room temperature with $28 \mu \mathrm{g} / \mathrm{ml}$ of papain or $6 \mu \mathrm{g} / \mathrm{ml}$ of proteinase $\mathrm{K}$ or $6 \mu \mathrm{g} / \mathrm{ml}$ of trypsin (Sigma) for $10 \mathrm{~min}$ then washed with RPMI. The concentration of each protease was adjusted to obtain less than $5 \%$ of cell death, with blue trypan staining.
2.7. Isotype of Immunoglobulines in the Phosphatidylserine Affinity Column Eluates

\subsubsection{Isolation of Plasma Membranes [18-20]}

Lymphocyte cells $\left(10^{8}\right.$ cells $)$ are suspended in a hypotonic medium (e.g. $30 \mathrm{mM} \mathrm{NaHCO} 3, \mathrm{pH} 7$ ), to be homogenized in a tight-fitting dounce homogenizer, inclusion in the suspension of $1 \mathrm{mM} \mathrm{ZnCl} 2$ stabilizes the plasma membranes, and then the pellet was obtained by centrifugation at $1000 \mathrm{~g}$ for $15 \mathrm{~min}$.

$200 \mathrm{ml}$ of $20 \%$ dextran, $103 \mathrm{ml}$ of $30 \%$ polyethyleneglycol (PEG) Carbowax 800, $33 \mathrm{ml}$ of $0.2 \mathrm{M}$ sodium phosphate $\mathrm{pH} 6.5$ and $179 \mathrm{ml}$ of distilled water are mixed and left at $4{ }^{\circ} \mathrm{C}$ for 24 hours to collect a top phase and bottom phase.

The pellet was resuspended in $10 \mathrm{ml}$ of the upper phase, then $10 \mathrm{ml}$ of lower phase is added to the suspension; and then the mixture was centrifuged at $2000 \mathrm{~g}$ for $15 \mathrm{~min}$ to collect plasma membranes at the interface of two phases.

\subsubsection{Phosphatidylserine Affinity Column [21, 22]}

Phosphatidylserine $10 \mathrm{mg}$ (Sigma) and cholesterol $50 \mathrm{mg}$ (Sigma) were dissolved in $1 \mathrm{ml}$ of ethanol, mixed with $10 \mathrm{ml}$ of acrylamide gel solution; then the mixture was incubated overnight at room temperature. The resulting gel was homogenized in gel particles, assembled into a column and equilibrated with PBS.

Plasma membranes diluted with $32 \mathrm{mls}$ of PBS went through the column at $15 \mathrm{mls} /$ hour. PBS is then infused through the column at $30 \mathrm{mls} /$ hour, to get all the unbound plasma membranes. And then $35 \mathrm{mls}$ of eluting buffers was passed through the column at $45 \mathrm{mls} /$ hour. The samples were pooled, dialysed and concentrated.

The acrylamide gel solution contains $15 \%$ acrylamide, $5 \%$ bisacrylamide, $100 \mu \mathrm{l}$ of $140 \mathrm{mg} / \mathrm{ml}$ ammonium persulfate and $5 \mu \mathrm{l}$ of TEMED. The eluting buffer contains $0.1 \mathrm{M}$ phosphate buffer $0.5 \mathrm{M} \mathrm{NaCl} \mathrm{pH} 7.3$ and $0.1 \mathrm{M}$ glycine- $\mathrm{HCl} \mathrm{pH} 2.5$.

\subsubsection{Screening of the Isotype of Immunoglobulins by Dot Blot [23]}

Column eluate sample was deposited on a blotting membrane; after this the blotting membrane was incubated with antibodies conjugated to alkaline phosphatase (anti$\operatorname{IgG}$, anti-IgD, anti-IgM) in a blocking solution for 2.5 hours at room temperature, then washed with washing solution. For revelation, the blotting membrane was incubated with $\mathrm{BCIP} / \mathrm{NBT}$ solution for $3 \mathrm{~min}$ at room temperature, then washed with $1 \%$ acetic acid.

The washing solution (Sigma) contains $20 \mathrm{mM}$ Tris-HCl, $\mathrm{pH} 7.5,0.9 \% \mathrm{NaCl}$ and $0.05 \%$ Tween 20 . The blocking solution (Sigma) contains washing solution and $1 \%$ BSA. The BCIP/NBT solution (Sigma) contains $0.48 \mathrm{mM} \mathrm{NBT} \mathrm{(nitro} \mathrm{blue}$ tetrazolium), $0.56 \mathrm{mM}$ BCIP (5-bromo-4-chloro-3-indolyl phosphate), $10 \mathrm{mM}$ Tris-HCl, pH 9.2 and $59.3 \mathrm{mM} \mathrm{MgCl} 2$.

\subsection{Statistics}

The lymphocytes PL binding ratios were compared by a non parametric test (Kolmogorov-Smirnov) and Student's $t$ test, using the Statework software. 


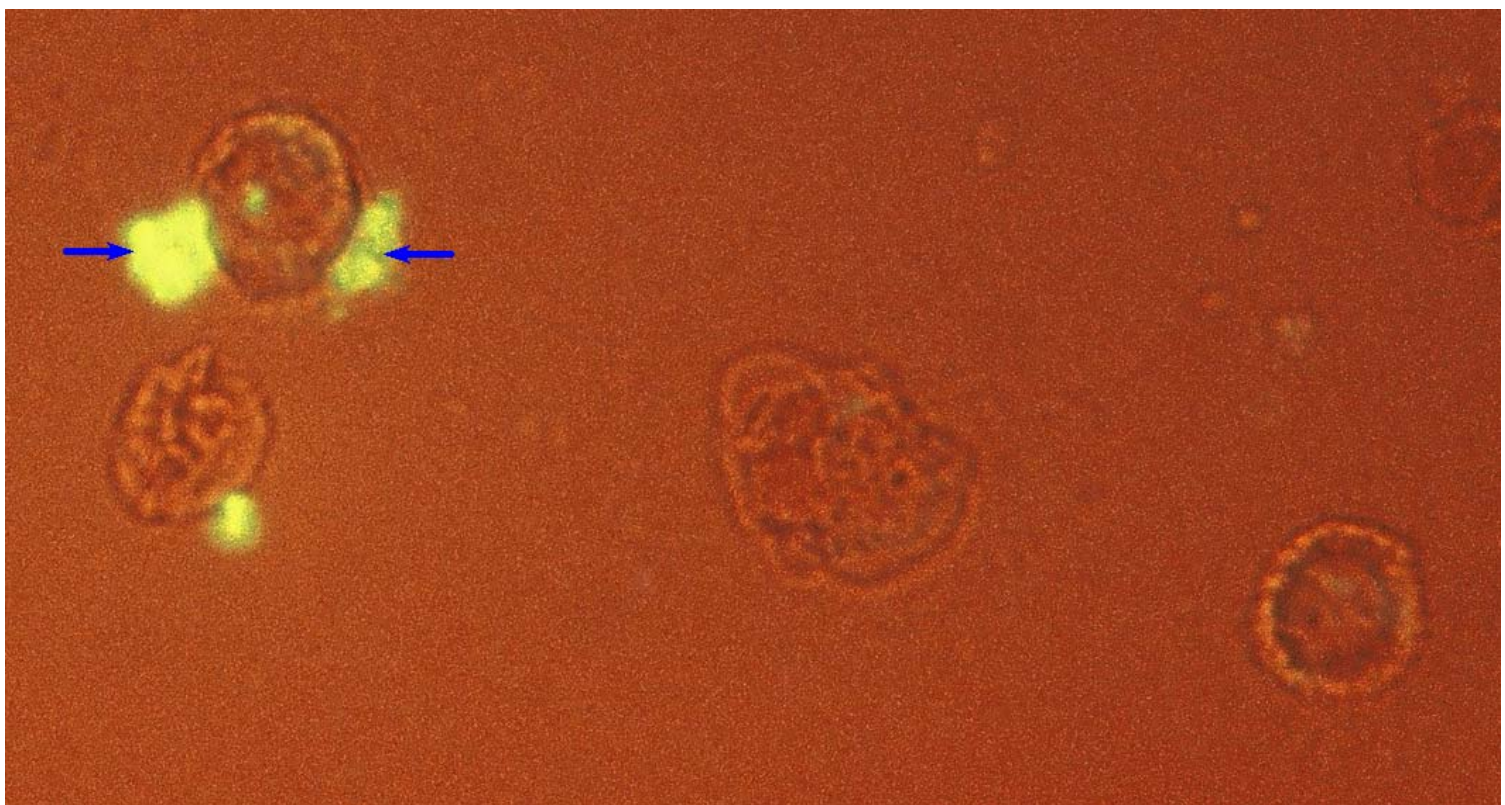

Fig. (1). Microphotography of lymphocytes binding PSL (x100). Healthy blood donor lymphocytes were incubated with FITC labelled PSL and analysed by fluorescence microscopy. The arrows show fluorescent PSL bound to the surface of lymphocytes.

\section{RESULTS}

Between $4-18 \%$ of healthy donor lymphocytes bind fluorescein labelled PS liposomes (PSL). Roughly similar results are obtained by flow cytometry or observation with fluorescence microscopy. By fluorescence microscopy, we do not observe any diffuse fluorescence on the surface of lymphocytes, thus we could exclude diffusion and passive fixation of fluorescein or fluorescein stained proteins (albumin or IgG) used for the labelling of PSL. The only fluorescence observed was in the PSL attached on the cell surface and in the cytoplasm of scarce mononuclear phagocytes (Fig. 1).

To compare the binding ratio of the lymphocytes according to the PLs (PS, CL, PE or PC), each of them was used to prepare liposomes or to coat Petri dishes. In 17 healthy donor lymphocytes, the binding ratios decrease in the order PS, CL, PE and PC (non parametric test $\mathrm{p}=0.02$ ) (Fig. 2). Binding to PC coated Petri dishes was similar to control Petri dishes.

The decrease of the binding ratios from PS, CL, PE to PC observed with whole lymphocyte population was confirmed with all the lymphocyte subpopulations studied, $\mathrm{CD} 9^{+} \mathrm{CD}^{-}, \mathrm{CD} 19^{+} \mathrm{CD}^{+}, \mathrm{TCD}^{+}, \mathrm{TCD}^{+}, \mathrm{T} \mathrm{CD} 8^{+}$, and $\mathrm{CD}^{+} 6^{+}$(NK cells).

The PLs binding ratio varies from one lymphocyte subpopulation to another. In 17 healthy donor lymphocytes, the highest binding values for PSL were observed with B cells $\left(\mathrm{CD} 19^{+}\right) 29 \pm 29.5 \%$, followed by $\mathrm{NK}\left(\mathrm{CD} 56^{+}\right)$ $16.6 \pm 10 \%$. The percentage of cells binding PSL binding cells was $9 \pm 8 \%$ for TCD $4^{+}, 8 \pm 3.7 \%$ for $\mathrm{TCD}^{+}$and $4 \pm 2 \%$ for TCD $8^{+}$(Fig. 3A-D). Similar results were observed with PS coated Petri dishes.

The PLs binding ratio varies also according to the $\mathrm{B}$ cells subset. The ratio of PS binding cells (in the Petri dish assay) in 17 healthy donors was $48.7 \pm 18 \%$ for $\operatorname{sIgM}^{+} \operatorname{sIgD}^{+} \mathrm{B}$ cells, $42.2 \pm 19 \%$ for $\operatorname{sIgA}^{+} \mathrm{B}$ cells and $14.8 \pm 11 \%$ for $\operatorname{sIgG}^{+} \mathrm{B}$ cells which had the lowest values $(\mathrm{p}<0.01)$ (Fig. 4). Results were quite similar between PS and CL coated Petri dishes, and between $\mathrm{CD}^{+}$and $\mathrm{CD}^{-} \mathrm{B}$ lymphocyte lineages (Table 1).

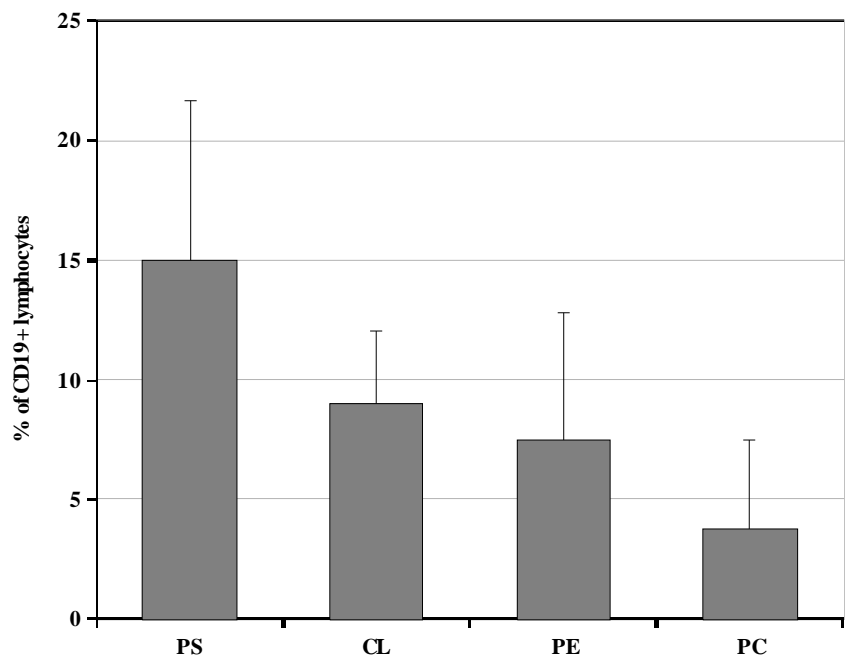

Fig. (2). Lymphocytes binding to different types of phospholipids. The lymphocytes adhering to Petri dishes coated with phosphatidylserine (PS) or cardiolipin (CL) or phosphatidylethanolamine (PE) or phosphatidylcholine (PC), were harvested with a rubber policeman and labelled with anti-CD19 $\mathrm{mAb}$, then analysed by flow cytometry. Peripheral blood lymphocytes were obtained from healthy donors and results represent the means \pm S.D of 17 donors.

With an aim of seeing whether the alterations of the populations of lymphocytes could influence the PL binding ratios, AIDS patients' lymphocytes were tested. PS binding ratios of $\mathrm{CD}^{+}$or $\mathrm{CD}^{-} \mathrm{B}$ lymphocyte lineages of 16 AIDS patients were not different from healthy donors (Table $\mathbf{1}$ and Fig. 5). Nor were different AIDS patients with IgG anticardiolipin antibodies $(n=4)$ from patients without antibodies 

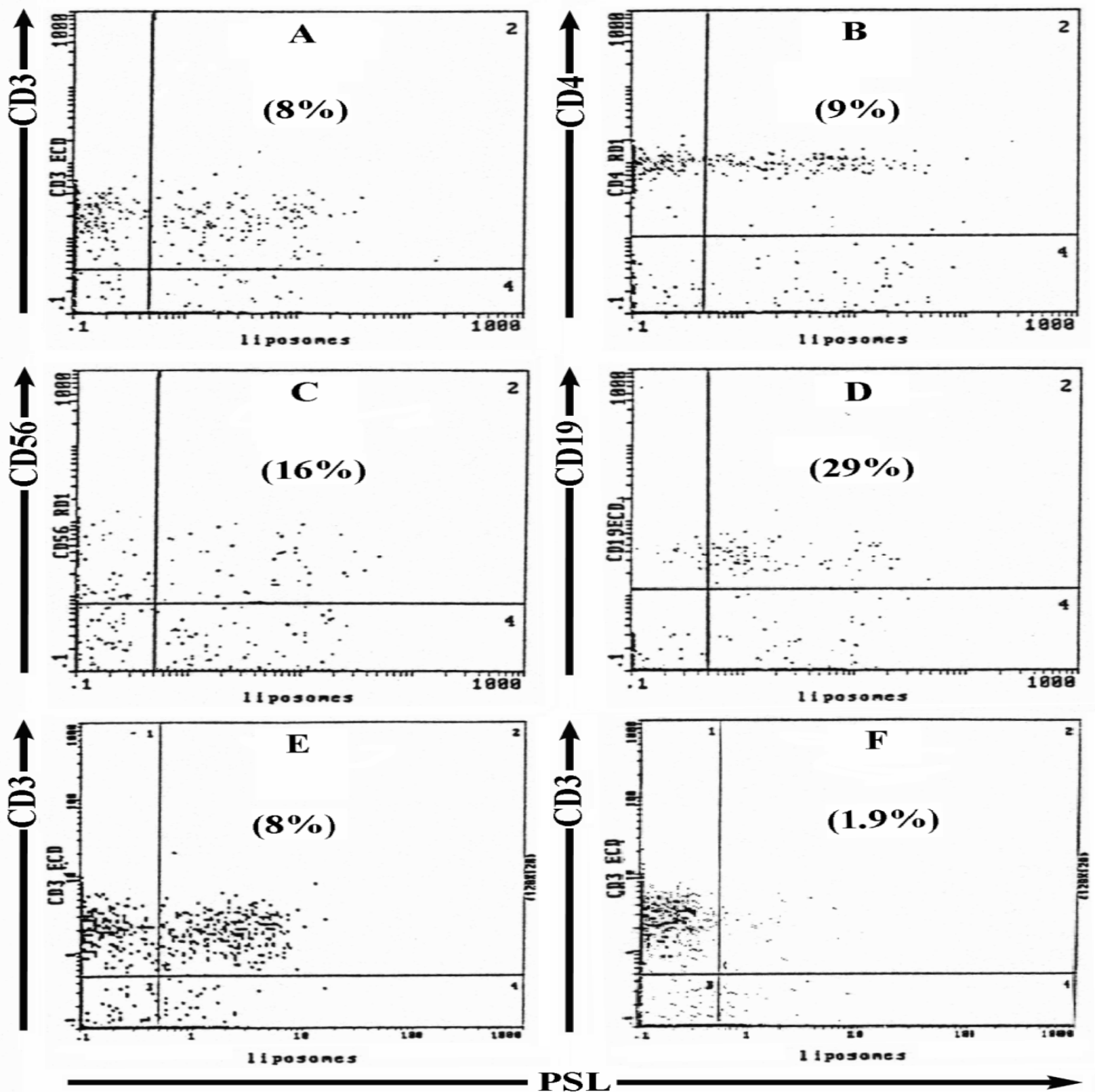

Fig. (3). The phenotypes of lymphocytes binding PSL. A to D: mononuclear blood cells were incubated with fluorescein stained PSL, after labelling with anti-CD mAb the phenotype of cells was determined by flow cytometry. The histograms show in $\mathrm{X}$ axis the green fluorescence due to PSL binding and in the Y axis the phenotype of cells labelled (A) with ECD conjugated anti-CD3, (B) RD1 conjugated anti-CD4, (C) RD1 conjugated anti-CD56 and (D) ECD conjugated anti-CD19. E to F: inhibition of PSL binding by preatreatment with proteases. The histogram E shows PSL binding by control non treated lymphocytes, F shows PSL binding by papain treated lymphocytes; only the histogram of the CD3 phenotype is shown. Histograms are those of a representative healthy donor. For each phenotype the number in parenthesis is the mean percentage observed with 17 healthy donors, each one tested two times.

$(\mathrm{n}=8)$. Results were similar either when PS or CL was used for coating Petri dishes.

Pretreatment of lymphocytes with proteases decreased binding to PSL (Fig. 3E, F) or PS coated Petri dish. Average inhibition with 8 healthy donor lymphocytes was of $86 \%$ with proteinase $\mathrm{K}, 76 \%$ with papain, and $63 \%$ with trypsin. Stronger inhibition was obtained by increasing the concentration of proteases (see material and methods), but the dead cell ratio increased also. Inhibition of PL binding was observed in all lymphocyte subpopulations. These results suggest that a protein or a set of proteins on the plasma membrane of lymphocytes could bind PLs.

Lymphocyte plasma membranes were isolated and perfused through a PS affinity column. Eluted material was deposited like a dot on a nitrocellulose membrane. The dot membrane was incubated with alkaline phosphatase 

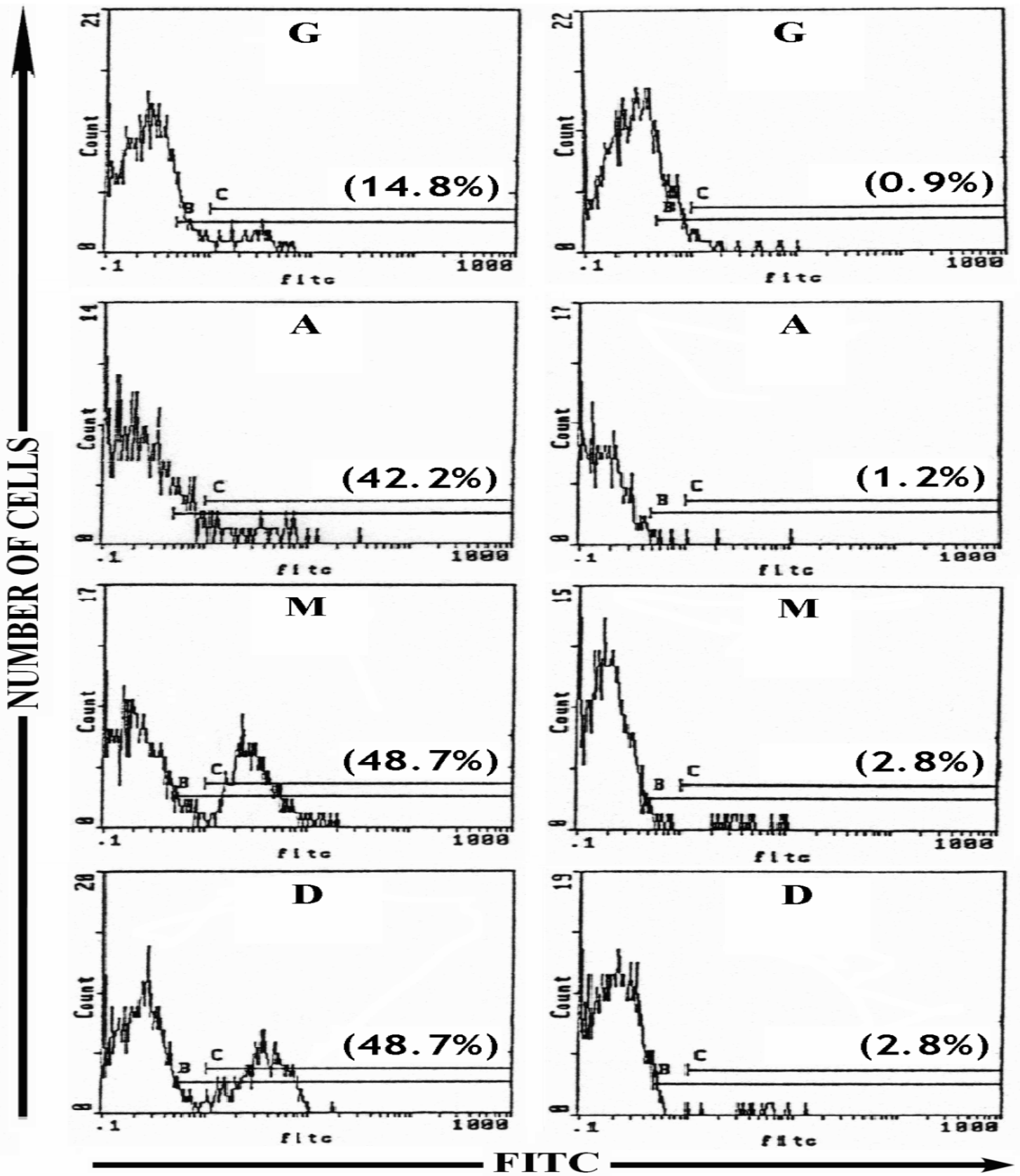

Fig. (4). Flow cytometric analysis for the surface immunoglobulins (sIg) of B lymphocytes binding PS in the Petri dish assay. Technical conditions were those of figure 2. Mononuclear cells harvested from Petri dishes were labelled with FITC conjugated anti-human Ig $\mathbf{G}, \mathbf{A}, \mathbf{M}$, and $\mathbf{D}$; then analysed by flow cytometry. Y axis is the number of cells, X axis is the green fluorescence due to FITC. The histograms show in $(\mathbf{G})$ the percentage of $\operatorname{sIgG}^{+}$cells, (A) $\operatorname{sIgA}^{+}$cells, $(\mathbf{M}) \operatorname{sIgM}^{+}$B cells and (D) $\operatorname{sIgD}^{+}$B cells. The right histograms shows the sIg of supernatant lymphocytes and the left histograms the sIg of lymphocytes binding PS. The first curve in all the histograms, is the background fluorescence of negative cells. The number in parenthesis is the mean percentage observed with 17 healthy donors, each one tested two times.

conjugated anti-isotype antibodies and then revealed with the substrate BCIP/NBT. The coloration of dots was dark with anti-IgD or anti-IgM, and pale with anti-IgG or anti-IgA (Fig. 6).

\section{DISCUSSION}

Many investigations have been done to study the receptors binding PL; in macrophage various candidate proteins have been evoked in the binding of cells expressing
PS, but the nature of the receptor(s) that mediate PS recognition remains unclear; scavenger receptors, a5ß33 integrin, CD36 and CD14 have been reported to bind PS [2427]. Class B scavenger receptors type I (SR-BI) and CD36 bind PS liposomes but not PC and PE liposomes [28]. SR-BI is a PS receptor which allows Sertoli cells to identify and phagocyte death cells [29] and CD36 represents a multifunctional adhesive receptor on a variety of cells such as monocytes and platelets. CD36 has been implicated in the 
Table 1. Adhesion of B Lymphocyte Subsets to PS Coated Petri Dishes in Healthy Donors and HIV Infected Patients

\begin{tabular}{|c|c|c|c|c|c|c|}
\hline \multirow{2}{*}{ Donor** } & \multicolumn{6}{|c|}{$\%$ of Each Lymphocyte Subset Binding PS* } \\
\cline { 2 - 7 } & $\mathbf{I g D}^{+} / \mathbf{5}^{-}$ & $\mathbf{I g D}^{+} / \mathbf{5}^{+}$ & $\mathbf{I g G}^{+} / \mathbf{5}^{-}$ & $\mathbf{I g G}^{+} / \mathbf{5}^{+}$ & $\mathbf{I g A}^{+} / \mathbf{5}^{-}$ & $\mathbf{I g A}^{+} / \mathbf{5}^{+}$ \\
\hline \hline Healthy & 48 & 22 & 10 & 7 & 40 & 18 \\
\hline Healthy & 19 & 20 & 11 & 8 & 31 & 27 \\
\hline AIDS & $39 * *$ & 58 & 10 & 5 & 31 & 28 \\
\hline AIDS & 38 & 52 & 3 & 2 & 50 \\
\hline
\end{tabular}

*The subsets of lymphocytes, $\mathrm{CD}^{+}\left(5^{+}\right)$or $\mathrm{CD}^{-}\left(5^{-}\right)$and the surface Ig are indicated.

**Two representative patiens from healthy and HIV infected groups are shown.

****This patient had 80 UGPL of IgG anticardiolipin autoantibodies.

removal of apoptotic or senescent cells [30]. A third receptor on macrophages, CD14, binds PS weaker than PI [31]. CD14 was involved in the recognition and phagocytosis of cells undergoing apoptosis [32]. A protein receptor on the surface of macrophages, fibroblasts and epithelial cells for phosphatidylserine-specific clearance of apoptotic cells and engulfment of apoptotic corpses was described [9, 33].

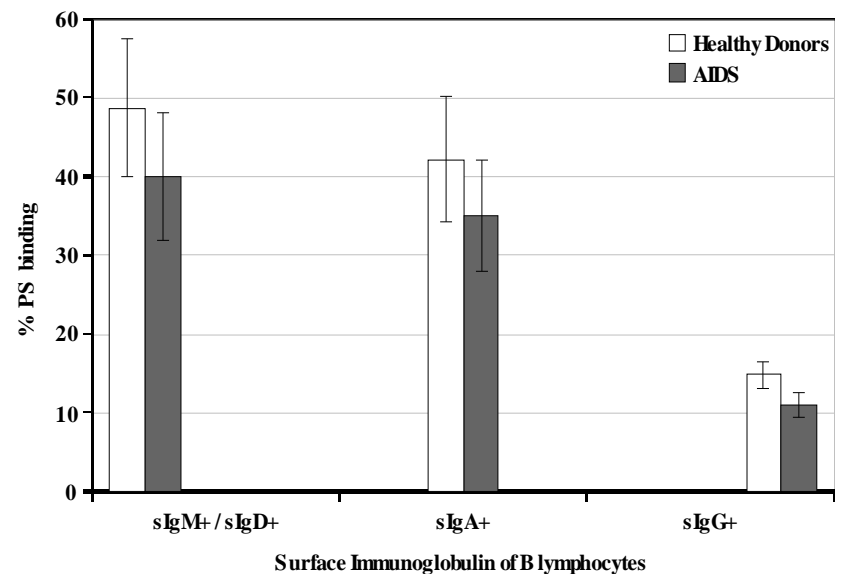

Fig. (5). B lymphocytes subsets binding PS coated Petri dishes. The lymphocytes, of healthy donors and AIDS patients, adhering to Petri dishes coated with phosphatidylserine (PS) were harvested with a rubber policeman and labelled with FITC conjugated antihuman Ig G, A, M and D; then analysed by flow cytometry. Results represent the means \pm S.D then the binding ratios of healthy $(n=17)$ and AIDS patients $(n=16)$ donor's B lymphocytes subsets.

Phosphatidylserine receptor (PSR) was identified by monoclonal antibodies mAb 217 [9]. PSR was localized in the nucleus; mAb 217 antigen is not expressed on lymphoid cells although it is expressed on the various cells [34]. Mitchell et al. [34] exclude this PSR from a functional role in innate apoptotic cell recognition and engulfment; they suggest that the designation of this gene product as a PSR is inappropriate.

Based on binding studies, mutagenesis and a co-crystal structure, Freeman GJ et al. [10] concluded that TIM (T cell/transmembrane, immunoglobulin, and mucin) are pattern recognition receptors specialized for recognition of PS. They provide a functional repertoire regulating the immune response of $\mathrm{T}$ lymphocytes against cells or exosomes expressing PS. TIM-1, TIM-3, and TIM-4 all bind PS; in this binding PS penetrates to the pocket called MILIBS (metal ion-dependent ligand-binding site). Asn and
Asp residues in the MILIBS coordinate with metal ions and PS. Asn and Asp residues are absent in TIM-2 therefore TIM-2 does not bind PS.

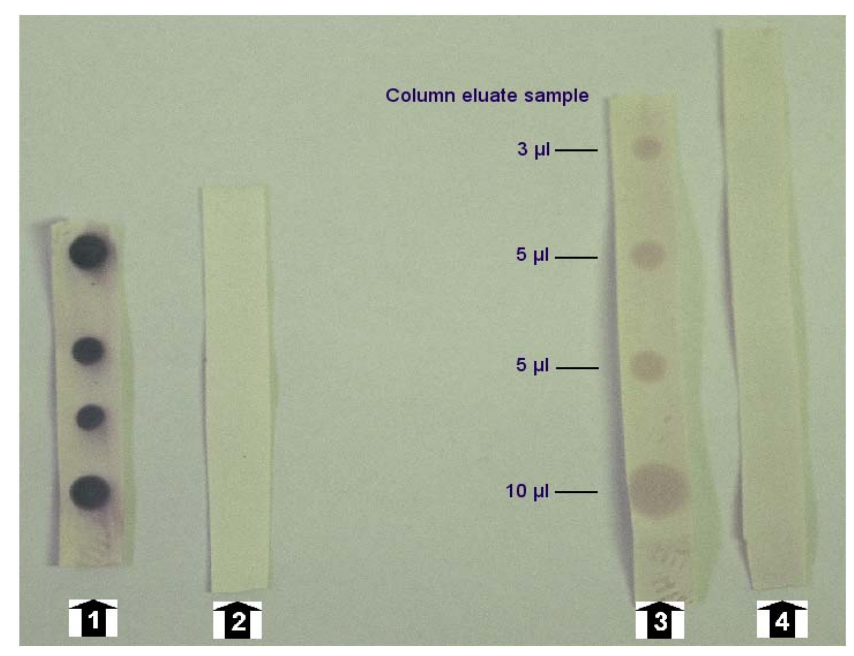

Fig. (6). Screening of the isotypes of immunoglobulins eluted from phosphatidylserine affinity column. Photography of dot blot. Lymphocyte plasma membranes were perfused through the column., after which aliquots of eluted fractions from the column and controls were dotted on a nitrocellulose blotting membrane and then incubated with anti-Ig G, A, M, D antibodies. Only results obtained with alkaline phosphatase conjugated anti-IgD antibodies and revealed with BCIP/NBT solution are shown. The arrow 3 shows dot blot with the affinity column eluate deposited at increasing volumes: from the top to bottom $3 \mu 1,5 \mu 1,5 \mu 1$ and 10 $\mu 1$. Control dot blots: the arrow 1 shows dots with $5 \mu 1,3 \mu 1,3 \mu 1$ and $5 \mu \mathrm{l}$ of $\operatorname{IgD}$ at $100 \mu \mathrm{g} / \mathrm{ml}$ and fixed on the membrane, the arrows 2 and 4 show respectively dot blot with blocking solution, and buffers used for the elution and dialysis.

TIM- 1 is expressed on CD4 ${ }^{+} \mathrm{T}$ cells and T helper 2 cells. TIM-3 is expressed on CD $4^{+} \mathrm{T}$ cells, T-helper 1 cells, CD8 ${ }^{+}$ T cells, NK cells, NKT cells, and at low levels on Th17 cells. In contrast to TIM-1 and TIM-3, TIM-4 is not expressed on $\mathrm{T}$ cells but is expressed exclusively on antigen-presenting cells; TIM-3 is also expressed on mast cells, macrophages, monocytes and dendritic cells [10]. Except low levels of TIM-1, no other TIM was described on B lymphocytes [10].

The CD1 family consists of five proteins (a-e) that are related to the MHC class I family. CD1 proteins have evolved as a separate lineage of antigen presenting molecules able to present microbial and self lipids to $\mathrm{T}$ lymphocytes. Crystal structures of mouse and human CD1d 
show how it binds and presents a diverse range of lipid ligands. The membrane distal $\alpha 1$ and $\alpha 2$ domains contain a hydrophobic ligand binding site that is comprised of two connected pockets, designated A' and F'. The A' pocket is filled by the lipid tail while the F' pocket is filled by the polar head [13].

B cells express CD1 and hence have the potential to present lipid antigens to Natural killer T (NKT) cells, they do so at a level equivalent to 2- to 3-fold lower than that of dendritic cells (DC). B lymphocytes suppress DC-mediated iNKT and NK cell activation and cell-cell contact is essential for this effect [35].

Activated and memory B cells express lower levels of CD1d compared with resting, naive, and marginal zone-like $\mathrm{B}$ cells. In vitro, CD1d is downregulated by all forms of $\mathrm{B}$ cell activation, CD1c expression and function also decrease following activation by CD40L alone, whereas activation via the BCR significantly upregulate CD1c, particularly on marginal zone-like B cells [36]. The higher PLs binding ratio of naïve $B$ lymphocytes than memory or effector $B$ lymphocytes that we observed might be explained by a difference in the density of CD1 on the cell membrane.

NKT cells are CD1d-restricted, lipid antigen-reactive T cells that express a limited array of $\alpha \beta \mathrm{T}$ cell receptors (TCRs), with the an invariant $\alpha$ chain (Vo24-Ja18 in humans) paired with particular TCR-V $\beta$ (V $\beta 11$ in humans). NKT cells are activated by microbial glycolipids as well as by self glycolipids or phospholipids such as phosphatidylinositol, phosphatidylglycerol, PE or PC [13, 37]. There is a growing body evidence to suggest that NKT cells have a powerful immunoregulatory potential against microbial or self antigens in autoimmune diseases.

The PLs binding ratios of human lymphocytes decrease in the order PS, CL, PE and PC. This binding might depend on the charge of the phospholipid head group, anionic PLs are bound better than zwiterionic PLs, or alternatively be PL specific. In a quantitative analysis of liposome-cell interaction the extent of liposome binding by human lymphocytes was 2-3 fold less than the extent by monocytes [38]. The binding of negatively charged PS/PC/cholesterol liposomes was several fold to an order of magnitude higher than that neutral PC/cholesterol liposomes. Maturation/ differentiation of monocytes in culture increases the binding ratio of negatively charged to neutral liposomes ratio from 5 to 30-40. In contrast, the lymphocytes did not show this dependency on the culture duration as this ratio in lymphocytes stayed around 10. The binding of PS-containing liposomes is mediated by binding sites that have strong affinity, comparable to or about an order of magnitude smaller than other known particle-cell interactions with specific receptors such as virus and lipoproteins binding to cells [38].

Though PL binding is not restricted to one lymphocyte subpopulation and seems rather ubiquitous, binding capacity seems to vary greatly between subpopulations. $\operatorname{IgM}^{+} \operatorname{IgD}^{+} \mathrm{B}$ cells are generally assumed to represent antigeninexperienced, naïve (virgin) B cells expressing variable region genes without somatic mutations. These cells represent nearly $60 \%$ of the peripheral $\mathrm{B}(\mathrm{PB})$ lymphocytes in humans and the remainder are memory B cells. Among 40
$\%$ of $\mathrm{V}$ gene mutated $\mathrm{B}$ cells $10 \%$ were $\operatorname{IgM}^{+}, 15 \%$ $\operatorname{IgM}^{+} \operatorname{IgD}^{+}$and $15 \% \mathrm{IgG}^{+}$or $\operatorname{IgA}^{+}[39]$. B cells can be further subdivided into $\mathrm{CD}^{+}$(B1) cells, 10-20\% of PB and $\mathrm{CD}^{-}$(B2) cells 80-90\%.

Among B lymphocytes, virgin B lymphocytes have the highest PLs binding ratio, and $\operatorname{sIgG}^{+}$memory $B$ cells have the lowest ratio. The receptor with the highest affinity might be the sIgM and sIgD (germline or $\mathrm{V}$ gene mutated ?). However, the low binding ratio of $\operatorname{sigG}^{+}$B cells suggests that $\mathrm{V}$ gene mutations decrease the affinity for PLs. The high proportion of PL binding naïve B cells suggests polyclonal binding and/or polyreactive $\operatorname{sgM}$ and $\operatorname{sigD}$. The proportion of B cell clones that might be committed to the production of aPL antibodies, though not exactly known, seems however relatively high, $21 \%$ of the primary lines of Epstein-Barr virus transformed human peripheral blood lymphocytes, produce IgG or IgM anti-cardiolipin antibodies [40]. Alternatively the higher density of CD1 on the membrane of virgin $B$ lymphocytes than on the membrane of memory or effector B lymphocytes [36] might explain the difference in PLs binding.

No significant difference in PLs binding is observed between $\mathrm{CD}^{+}$and $\mathrm{CD}^{-} \mathrm{B}$ lymphocyte lineages. Because polyreactive natural autoantibodies are produced by the $\mathrm{CD}^{+}$B lymphocyte lineage, the membrane bound anti-PLs natural autoantibodies cannot be the explanation of the high ratio of naïve $\mathrm{B}$ cells binding to PLs.

B-1a $\left(\mathrm{CD}^{+}\right)$cells producing natural IgM anti-PC antibodies were originally recognized because they lyse bromelain-treated mouse erythrocytes in a complementdependent plaque forming cell assay. These cells, although constituting only a minor fraction of B cells in spleen and lymph nodes of mice, represent the main B-cell population in the peritoneal and pleural cavities [41]. Up to $15 \%$ of peritoneal B-1a cells in all normal mouse bind PC. They produce most of the natural antibodies in serum and contribute significantly to the IgA producing plasma cells in the lamina propria of the gut. Half of the serum IgA and a significant amount of the spontaneously produced (natural) $\mathrm{IgG}$ in serum are produced by isotype-switched progeny of B-1a cells [42]. They participate in relatively few, antigen stimulated antibody responses, mostly those stimulated by Tindependent antigens. B-1b cells lack surface CD5, though they possess mRNA for CD5 [43]. B-1b or B-2 (CD5 $\left.{ }^{-}\right)$cells are transiently induced to express CD5 in the follicular mantle zones of secondary lymphoid tissues [44].

Though similarities are observed with our results specially the high proportion of naïve B lymphocytes binding PS, contradictions are multiple. No difference were found in avidity to PLs between $\mathrm{CD}^{+}$and $\mathrm{CD}^{-} \mathrm{B}$ cells, and $\mathrm{PC}$ was the $\mathrm{PL}$ with the lowest binding ratio. However in these studies realized with mouse lymphocytes, PS and PC were not systematically compared with regard to their affinity. Human IgM aPC has been recognized for several years, but information regarding $\mathrm{aPC}$ as antibodies to bromelain-treated healthy human erythrocytes is scant [45]. They have been associated with polyreactive natural autoantibodies [46].

Wadee AA et al. [12] Indicated that PE and phosphatidylinositol (PI) bind actively and separately to 
lymphocytes, they described that the receptors for these two phospholipids on the surface of lymphocytes were trypsine and heat sensitive. Our results with protease treated lymphocytes suggest that a surface protein or a set of surface proteins bind PL. Moreover IgM and IgD were eluted from a PS affinity column perfused with lymphocytes plasma membranes fragments. The question arises of knowing who bind directly PS, $\operatorname{IgM}$ and $\operatorname{IgD}$, or another membrane protein close or linked to membrane Ig. Such a protein might be the $\mathrm{CD} 1$ or a receptor for $\mathrm{PS}$, perhaps a pattern recognition receptor specialized for recognition of PS similar to TIM receptors, with increased density on naïve B lymphocytes.

The TIM gene family plays a role in asthma, autoimmunity, tolerance and viral infection. In $\mathrm{HIV}^{+}$ patients, TIM-3 is expressed on approximately $50 \%$ of $\mathrm{CD}^{+}$ T cells against $28 \%$ in non HIV patients [10]. In contrast we observed similar PL binding by the B cell subsets in AIDS patients and non HIV control patients. HIV infection is associated with widespread abnormalities in the immune system, the destruction of TCD4 population being the major one. In these patients a high prevalence of antibodies to PL was reported, and we previously showed that anti-PC (zwiterionic PL) antibodies are found as frequent as anti-CL (anionic PL) antibodies [15]. However, PL binding ratios of B lymphocyte subsets of AIDS patients or patients with IgG anti-CL autoantibodies were not different from healthy donors. These contradictions could be explained by the fact that the majority of PL binding cells are naïve B cells which express CD1, a lipid presenting molecule, and these cells remain relatively constant whatever the immune status of the patient, including patients producing IgG anti-CL antibodies. Though this conclusion needs to be confirmed with more patients producing anti-CL antibodies, because in our study the number of patients included $(n=4)$ was small.

In conclusion, binding to PLs was observed with all the lymphocyte subpopulations studied. Virgin B lymphocytes show the highest binding ratios to PLs. No difference in binding ratios was observed between $\mathrm{CD}^{+}$and $\mathrm{CD}^{-} \mathrm{B}$ lymphocyte lineages. Anionic PLs had stronger avidity than zwiterionic PLs in binding to lymphocyte surface proteins. For each type of lymphocytes various kinds of surface proteins bind lipids, pattern recognition receptors, surface immunoglobulins, the lipid antigen presenting molecules $\mathrm{CD} 1$, and the CD1-restricted lipid antigen reactive TCR of NKT. Does the subpopulation binding PS participate in removing or destroying senescent and apoptotic cells, malignant cancers, modulating the innate immunity against microbial infections or suppressing anti-PLs antibodies? This question and the respective role of PLs binding receptors or antigen presenting molecules need to be further studied.

\section{ACKNOWLEDGEMENT}

We thank Marie-Hélène Maës, Lucienne Massé and Marie-Antoinette Ranguin AP-HP for helpful assistance. This work was supported by Association Claude Bernard and Robert Debré.

\section{CONFLICT OF INTEREST}

The authors confirm that this article content has no conflicts of interest.
ABBREVIATIONS
aPL
$=$ Anti-phospholipid antibodies
CL
$=$ Cardiolipin
PE
$=$ Phosphatidylethanolamine
PC
$=$ Phosphatidylcholine
PLs
$=$ Phospholipids
PS
$=$ Phosphatidylserine
PI
$=$ Phosphatidylinositol
PSL
$=$ Phosphatidylserine liposomes
NKT
$=$ Natural killer T cells
TIM
$=\mathrm{T}$ cell/transmembrane, immunoglobulin, and mucin, pattern recognition receptors
$\mathrm{NK} \quad=$ Natural killer cells
NKT $=$ Natural killer T lymphocytes
$\operatorname{sIgM}^{+} \operatorname{sIgD}{ }^{+}=$Surface IgM and $\operatorname{IgD}$

\section{REFERENCES}

[1] Galli M, Bevers EM. Blood cell lipid asymmetry and antiphospholipid antibodies. Haemostasis 1994; 24: 183-90.

[2] Sestier C, Sabolovic D, Geldwerth D, et al. Use of annexin Vferrofluid to enumerate erythrocytes damaged in various pathologies or during storage in vitro. C R Acad Sci III 1995; 318: 1141-6.

[3] Moumaris M, Sestier C, Miltgen F, Halbreitch A, Gentilini M, Sabolovic D. Effect of fatty acid treatment in cerebral malariasusceptible and nonsusceptible strains of mice. J Parasitol 1995; 81: 997-9.

[4] Pelassy C, Breittmayer JP, Aussel C. Regulation of phosphatidylserine exposure at the cell surface by the serine-base exchange enzyme system during CD95-induced apoptosis. Biochem Pharmacol 2000; 59: 855-63.

[5] Hirt UA, Gantner F, Leist M. Phagocytosis of nonapoptotic cells dying by caspase-independent mechanisms. J Immunol 2000; 164: 6520-9.

[6] Fadok VA, Voelker DR, Campbell PA, Cohen JJ, Bratton DL, Henson PM. Exposure of phosphatidylserine on the surface of apoptotic lymphocytes triggers specific recognition and removal by macrophages. J Immunol 1992; 148: 2207-16.

[7] Verhoven B, Schlegel RA, Williamson P. Mechanisms of phosphatidylserine exposure, a phagocyte recognition signal, on apoptotic T lymphocytes. J Exp Med 1995; 182: 1597-601.

[8] Savill J, Fadok V, Henson P, Haslett C. Phagocyte recognition of cells undergoing apoptosis. Immunol Today 1993; 14: 131-6.

[9] Fadok VA, Bratton DL, Rose DM, Pearson A, Ezekewitz RA, Henson PM. A receptor for phosphatidylserine-specific clearance of apoptotic cells. Nature 2000; 405: 85-90.

[10] Freeman GJ, Casasnovas JM, Umetsu DT, DeKruyff RH. TIM genes: a family of cell surface phosphatidylserine receptors that regulate innate and adaptive immunity. Immunol Rev 2010; 235 : 172-89.

[11] Wadee AA, Sher R, Rabson AR. Production of a suppressor factor by human adherent cells treated with mycobacteria. J Immunol 1980; 125: 1380-6.

[12] Wadee AA, Rabson AR. Binding of phosphatidylethanolamine and phosphatidylinositol to OKT8 lymphocytes activates suppressor cell activity. J Immunol 1983; 130: 2271-6.

[13] Venkataswamy MM, Porcelli SA. Lipid and glycolipid antigens of CD1d-restricted natural killer T cells. Semin Immunol 2010; 22: 68-78.

[14] Moumaris M, Benoliel S, Rouquette AM, Rajoely B, Abuaf N. Phospholipid binding proteins on the plasma membrane of lymphocytes. J Autoimmun 2000; 15: A33.

[15] Abuaf N, Laperche S, Rajoely B, et al. Autoantibodies to phospholipids and to the coagulation proteins in AIDS. Thromb Haemost 1997; 77: 856-61. 
[16] Mercolino TJ, Locke AL, Afshari A, et al. Restricted immunoglobulin variable region gene usage by normal Ly-1 $\left(\mathrm{CD}^{+}\right) \mathrm{B}$ cells that recognize phosphatidylcholine. J Exp Med 1989; 169: 1869-77.

[17] Schneider E, Whitmore S, Glynn KM, et al. Centers for Disease Control and Prevention (CDC). Revised surveillance case definitions for HIV infection among adults, adolescents, and children aged $<18$ months and for HIV infection and AIDS among children aged 18 months to $<13$ years--United States, 2008. MMWR Recomm Rep 2008; 57:1-12.

[18] Brunette DM, Till JE. A rapid method for the isolation of L-cell surface membranes using an aqueous two phase polymer system. J Membr Biol 1971; 5: 215-24.

[19] Gruber MY, Cheng KH, Lepock JR, Thompson JE. Improved yield of plasma membrane from mammalian cells through modifications of the two-phase polymer isolation procedure. Anal Biochem 1984; 138: 112-8.

[20] Findlay JBC, Evans WH. Biological membranes. The practical approach III series. USA: Oxford University Press 1990.

[21] Uchida T, Filburn CR. Affinity chromatography of protein kinase C-phorbol ester receptor on polyacrylamide-immobilized phosphatidylserine. J Biol Chem 1984; 259: 12311-4.

[22] McNeil HP, Krillis SA, Chesterman CN. Purification of antiphospholipid antibodies using a new affinity method. Thromb Res 1988; 52: 641-8.

[23] Stott DI. Immunoblotting and dot blotting. J Immunol Methods 1989; 119: 153-87.

[24] Fadok VA, Warner ML, Bratton DL, Henson PM. CD36 is required for phagocytosis of apoptotic cells by human macrophages that use either a phosphatidylserine receptor or the vitronectin receptor $\left(\alpha_{\mathrm{V}} \beta_{3}\right)$. J Immunol 1998; 161: 6250-7.

[25] Sambrano GR, Steinberg D. Recognition of oxidatively damaged and apoptotic cells by an oxidized low density lipoprotein receptor on mouse peritoneal macrophages: Role of membrane phosphatidylserine. Proc Natl Acad Sci USA 1995; 92: 1396-400.

[26] Platt N, Suzuki H, Kurihara Y, Kodama T, Gordon S. Role for the class A macrophage scavenger receptor in the phagocytosis of apoptotic thymocytes in vitro. Proc Natl Acad Sci USA 1996; 93: 12456-60.

[27] Brown SB, Clarke MCH, Magowan L, Sanderson H, Savill J. Constitutive death of platelets leading to scavenger receptormediated phagocytosis. J Biol Chem 2000; 275: 5987-96.

[28] Rigotti A, Acton SL, Krieger M. The class B scavenger receptors SR-BI and CD36 are receptors for anionic phospholipids. J Biol Chem 1995; 270: 16221-4.

[29] Shiratsuchi A, Kawasaki Y, Ikemoto M, Arai H, Nakanishi Y. Role of class B scavenger receptor type I in phagocytosis of apoptotic rat spermatogenic cells by sertoli cells. J Biol Chem 1999; 274: 59018 .

[30] Yamaguchi A, Yamamoto N, Akamatsu N, et al. PS-liposome and Ox-LDL bind to different sites of the immunodominant domain
(\#155-183) of CD36: A study with GS95, a new anti-CD36 monoclonal antibody. Thromb Res 2000; 97: 317-26.

[31] Wang PY, Kitchens RL, Munford RS. Phosphatidylinositides bind to plasma membrane CD14 and can prevent monocyte activation by bacterial lipopolysaccharide. J Biol Chem 1998; 273: 24309-13.

[32] Devitt A, Moffatt OD, Raykundalia C, Capra JD, Simmons DL, Gregory CD. Human CD14 mediates recognition and phagocytosis of apoptotic cells. Nature 1998; 392: 505-9.

[33] Li W, Baker NE. The active role of corpse engulfment pathways during cell competition. Fly 2007; 1: 274-8.

[34] Mitchell JE, Cvetanovic M, Tibrewal N, et al. The presumptive phosphatidylserine receptor is dispensable for innate antiinflammatory recognition and clearance of apoptotic cells. J Biol Chem 2006; 281: 5718-25.

[35] Bezbradica JS, Stanic AK, Matsuki N, et al. Distinct roles of dendritic cells and B cells in Va14Ja18 natural T cell activation in vivo. J Immunol 2005; 174: 4696-705.

[36] Allan LL, Stax AM, Zheng DJ, et al. CD1d and CD1c expression in human B cells is regulated by activation and retinoic acid receptor signaling. J Immunol 2011; 186: 5261-72.

[37] Godfrey DI, Rossjohn J. New ways to turn on NKT cells. J Exp Med 2011; 208: 1121-5.

[38] Lee KD, Nir S, Papahadjopoulos D. Quantitative analysis of liposome-cell interactions in vitro: rate constants of binding and endocytosis with suspension and adherent J774 cells and human monocytes. Biochemistry 1993; 32: 889-99.

[39] Klein U, Rajewsky K, Küppers R. Human immunoglobulin (Ig) $\mathrm{M}^{+}$ $\mathrm{IgD}^{+}$peripheral blood $\mathrm{B}$ cells expressing the $\mathrm{CD} 27$ cell surface antigen carry somatically mutated variable region genes: CD27 as a general marker for somatically mutated (memory) B cells. J Exp Med 1998; 188: 1679-89.

[40] Lefvert AK. Heterogeneity of autoantibodies against cardiolipin and oxidatively modified LDLs revealed by human monoclonal antibodies. J Intern Med 2000; 247: 385-90.

[41] Herzenberg LA. B-1 cells: the lineage question revisited. Immunol Rev 2000; 175: 9-22.

[42] Baumgarth N, Herman OC, Jager GC, Brown L, Herzenberg LA. Innate and acquired humoral immunities to influenza virus are mediated by distinct arms of the immune system. Proc Natl Acad Sci USA 1999; 96: 2250-5.

[43] Kasaian MT, Ikematsu H, Casali P. Identification and analysis of a novel human surface $\mathrm{CD}^{-} \mathrm{B}$ lymphocyte subset producing natural antibodies. J Immunol 1992; 148: 2690-702.

[44] Youinou P, Jamin C, Lydyard PM. CD5 expression in human Bcell populations. Immunol Today 1999; 20: 312-6.

[45] Cabral AR, Cabiedes J, Alarcon-Segovia D. Hemolytic anemia related to an $\operatorname{IgM}$ autoantibody to phosphatidylcholine that binds in vitro to stored and to bromelain-treated human erythrocytes. J Autoimmun 1990; 3: 773-87.

[46] Avrameas S. Natural autoantibodies: from 'horror autotoxicus' to 'gnothi seauton'. Immunol Today 1991; 12: 154-9. 